\title{
IDENTIFIKASI PENGARUH UMUR PESAWAT TERHADAP TINGKAT KECELAKAAN PESAWAT PADA SETIAP TIPE MASKAPAI PENERBANGAN (REGIONAL, FULL SERVICE, DAN LOW COST CARRIER)
}

\author{
${ }^{1}$ Rianita Puspa Sari, ${ }^{2}$ Dene Herwanto \\ 1,2Program Studi Teknik Industri Universitas Singaperbangsa, Jl. H.S. Ronggowaluyo Teluk Jambe Karawang 41361 \\ e-mail: rianita.puspasari@yahoo.co.id
}

\begin{abstract}
Abstrak
Peningkatan mobilitas penduduk dunia menjadikan penggunaan pesawat terbang sebagai alternatif transportasi yang sering digunakan masyarakat. Penggunaan pesawat terbang tidak lepas kaitannya dengan keselamatan dan keamanan penerbangan. Negara yang memiliki standar tingkat keselamatan tinggi, sangat peka dan kritis terhadap masalah kecelakaan. Kecelakaan pesawat mendorong masyarakat untuk lebih memerhatikan keamanan dan keselamatan maskapai penerbangan. Penelitian ini bertujuan untuk mengetahui pengaruh umur pesawat dari suatu maskapai penerbangan terhadap jumlah kecelakaan. Maskapai yang diteliti berjumlah 202 maskapai penerbangan, dengan data diambil dari airlinesrating.com. Masing-masing maskapai penerbangan berasal dari negara yang berbeda-beda. Metode analisis Time Series-Causality Granger digunakan untuk mengetahui apakah umur pesawat memengaruhi jumlah kecelakaan. Uji tabulasi silang juga dilakukan untuk mengetahui karakter masing-masing kategori maskapai penerbangan. Hasil penelitian menunjukkan angka korelasi antara variabel umur pesawat dengan variabel tingkat kecelakaan pesawat adalah sebesar 0,009. Hal ini mengindikasikan tidak terjadi autokorelasi pada model regresi. Signifikansi model sebesar 0,017 menunjukkan bahwa $\mathrm{H}_{0}$ ditolak dan dapat disimpulkan terdapat hubungan yang signifikan antara umur pesawat dengan tingkat kecelakaan. Hasil analisis tabulasi silang mengindikasikan dari tingkat keselamatan, tipe maskapai kategori regional memiliki tingkat keselamatan yang sama dengan maskapai kategori full-service dan kategori low-cost carrier memiliki nilai yang paling rendah dari ketiga kategori maskapai.
\end{abstract}

Kata kunci : Time series; tingkat keselamatan; kecelakaan pesawat; penerbangan

\section{PENDAHULUAN}

Transportasi udara menjadi sebuah solusi dalam memperlancar arus pengangkutan, baik bagi penumpang maupung barang dari luar negeri karena dirasakan efektif dan efisien dalam menggunakan sarana transportasi ini. Perkembangan lalu lintas udara dan kondisi iklim yang semakin tidak stabil telah membawa tekanan besar untuk keselamatan penerbangan. Dalam undang-undang nomor 1 tahun 2009 tentang penerbangan, didefinisikan bahwa keselamatan penerbangan adalah suatu keadaan selamat dengan terpenuhinya semua persyaratan keselamatan dalam pemanfaatan wilayah udara, pesawat udara, bandar udara dan angkutan udara, navigasi penerbangan, serta fasilitas penunjang dan fasilitas umum lainnya (ICAO, 2014).

Sebuah kecelakaan pesawat terbang komersial yang terjadi di wilayah hukum sebuah negara, baik yang disertai atau tidak disertai dengan jatuhnya korban jiwa (fatal / nonfatal accident). Statistik kecelakaan dari tahun ke tahun memiliki tren fluktuatif. Namun secara keseluruhan mengindikasikan penurunan tingkat kecelakaan. Angka kecelakaan menurun sebanyak 5\% pada tahun 2015 dibandingkan tahun 2014 sehingga masih ada indikasi tren positif untuk keselamatan transportasi udara. Jumlah kematian pada tahun 2013, yaitu 173 merupakan jumlah paling sedikit korban jiwa dalam penerbangan komersial transportasi udara sejak tahun 2000 (ICAO, 2016).

Keselamatan dalam transportasi udara tergantung pada operasi back-office yang kompleks dalam keterlibatan penerbangan, kontrol lalu lintas udara dan bandara, serta kebutuhan lainnya. Apabila kecelakaan transportasi udara terjadi, hal tersebut akan menjadi penyebab utama yang dapat merusak kepercayaan penumpang dan masyarakat umum terhadap maskapai penerbangan. Oleh karena itu, meskipun kondisi keamanan transportasi udara lebih baik dibandingkan dengan kereta api, jalan dan transportasi air, manajemen keselamatan merupakan faktor mendasar bagi 
berlangsungnya layanan ini (Pachecho dkk., 2014). Untuk membuat penerbangan lebih aman bagi masyarakat umum maka harus dipahami mengapa kecelakaan terjadi sehingga dapat diusahakan supaya kecelakaan yang sama tidak terulang lagi. (Winarto, 2012)

Menurut ATSB Transport Safety Report (2007), di seluruh dunia telah terjadi kecelakaan pesawat yang berkaitan dengan umur pesawat. Umur pesawat terbang adalah kombinasi dari usia kronologis, jumlah siklus penerbangan dan jumlah jam terbang. Saat terjadi kecelakaan, pesawat sudah beroperasi belasan tahun, dan telah mengumpulkan sejumlah besar siklus penerbangan. Peraturan Menteri Perhubungan Nomor 7 Tahun 2016 adalah tentang perubahan atas Peraturan Menteri Perhubungan Nomor 160 Tahun 2015 tentang Peremajaan Armada Pesawat Udara Angkutan Udara Niaga. Dalam peraturan tersebut, umur pesawat kargo sebelum didaftarkan atau di registrasi, ditetapkan maksimal 25 tahun. Setelah didaftarkan atau diizinkan untuk beroperasi, pesawat kargo hanya boleh sampai berusia 40 tahun. (JDIH Kementrian Perhubungan, 2016)

Tingkat kecelakaan pesawat terbang didefinisikan sebagai jumlah kecelakaan yang terjadi dibagi dengan armada jumlah pesawat dari tahun ke tahun. Untuk tingkat kecelakaan tahunan, dilihat hanya jumlah kecelakaan yang terjadi pada tahun tertentu dibagi dengan jumlah pesawat layanan komersil. Saat mengevaluasi efek umur pesawat, maka dipertimbangkan jumlah total kecelakaan pesawat terbang pada umur tertentu dengan jumlah pesawat terbang yang melakukan penerbangan sesuai jam terbang (Hansman, 2014). Seiring berjalannya waktu, umur pesawat yang awalnya berstatus "brand new" mulai bertambah dan bertambah pula jenis dan tingkat kerusakannya sehingga tingkat perawatannya juga bertambah. Jika tidak dilakukan perawatan ketat oleh petugas teknis, maka peluang terjadinya insiden dan kecelakaan akan semakin terbuka (ICAO Indonesia, 2016). Pada penelitian ini dilakukan analisis pengaruh umur pesawat terhadap jumlah kecelakaan maskapai penerbangan, serta mengetahui karakteristik dari tiap kategori maskapai penerbangan untuk menganalisis lebih lanjut keadaan keselamatan penerbangan.

\section{METODE PENELITIAN}

Pada penelitian ini, acuan yang dipakai untuk membuat metodologi penelitian adalah kerangka berpikir yang dikembangkan oleh Sekaran (2003). Proses penelitian ini secara garis besar dibagi ke dalam empat tahapan, yaitu tahap pendahuluan, perancangan kerangka kerja teoretis, pengumpulan dan pengolahan data, hingga tahap analisis dan penarikan kesimpulan. Gambar 1. merupakan tahapan penelitian yang dilakukan. 


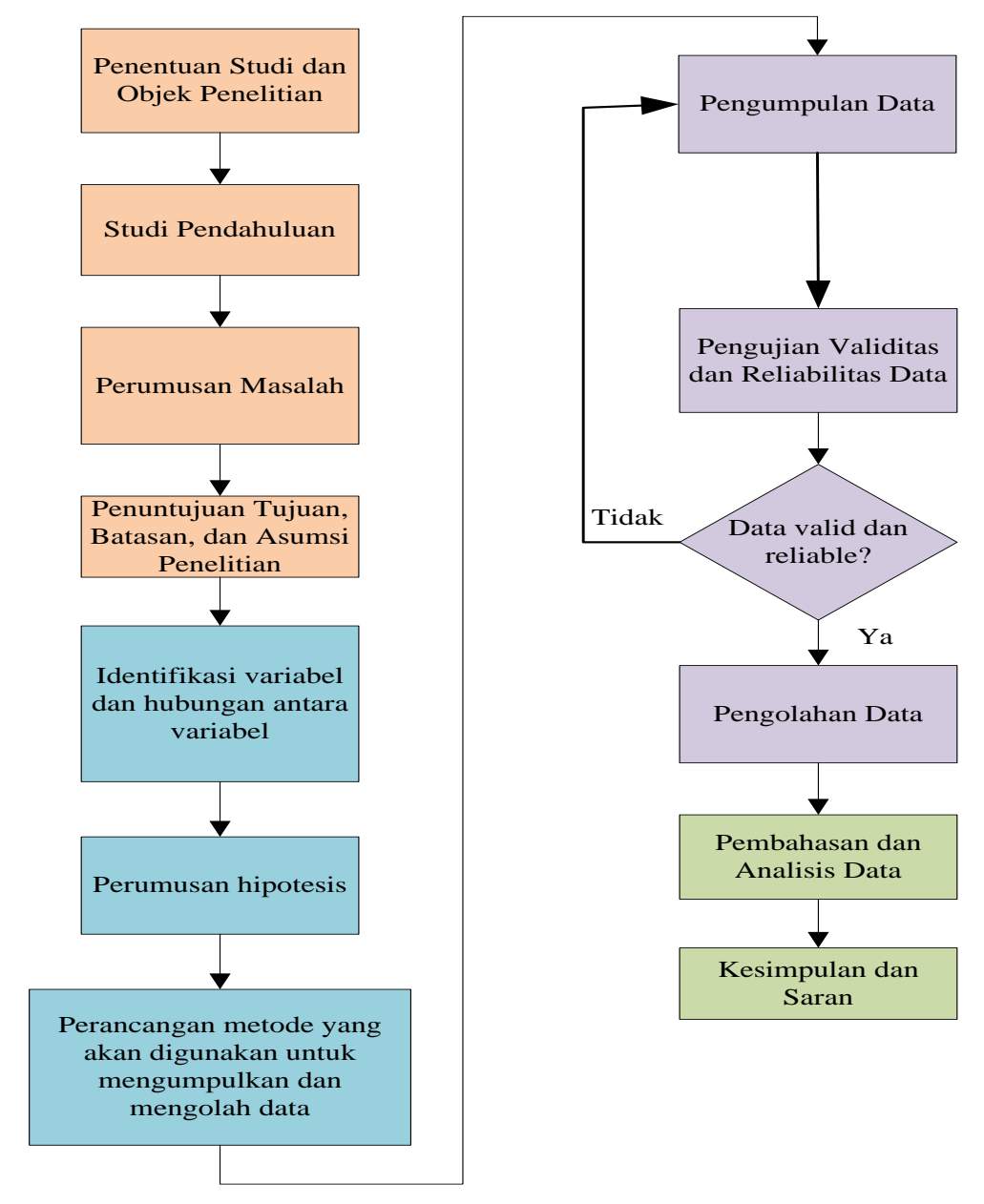

Gambar 1. Flowchart Metodologi Penelitian

Dalam mengumpulkan data, metode yang dipakai peneliti adalah pencarian data sekunder mengenai faktor-faktor apa saja yang memengaruhi nilai safety rating dari suatu maskapai penerbangan dengan menggunakan internet. Pengolahan data dilakukan dengan menggunakan metode-metode statistika, Time series analysis digunakan untuk mengetahui apakah umur pesawat memengaruhi jumlah kecelakaan pesawat, sedangkan uji tabulasi silang digunakan untuk mengetahui karakter masing-masing tipe maskapai penerbangan dari tingkat keselamatan. Data yang telah lengkap kemudian dilakukan pengujian validitas dan reliabilitas, apabila data tersebut lolos uji, maka data akan segera diolah. Namun, apabila data tidak lolos uji, maka di asumsikan adanya kesalahan dalam pengambilan data sehingga data harus diambil kembali.

\section{HASIL DAN PEMBAHASAN}

Pengolahan data pada tahap ini digunakan untuk menguji hipotesis bahwa average age of fleet memengaruhi kecelakaan pesawat. Data sekunder awal untuk pengolahan data di tahap ini didapatkan dari IATA: World Air Transport Statistics 2012. Data mentah selengkapnya dapat dilihat pada Lampiran B. Sebelum dilakukan pengujian Granger, data yang akan digunakan diuji terlebih dahulu stasioneritasnya. Pengujian stasioneritas dilakukan menggunakan AutoCorrelation Function (ACF) pada software SPSS 20. Hasil pengujian tersebut dapat dilihat pada Gambar 2. 

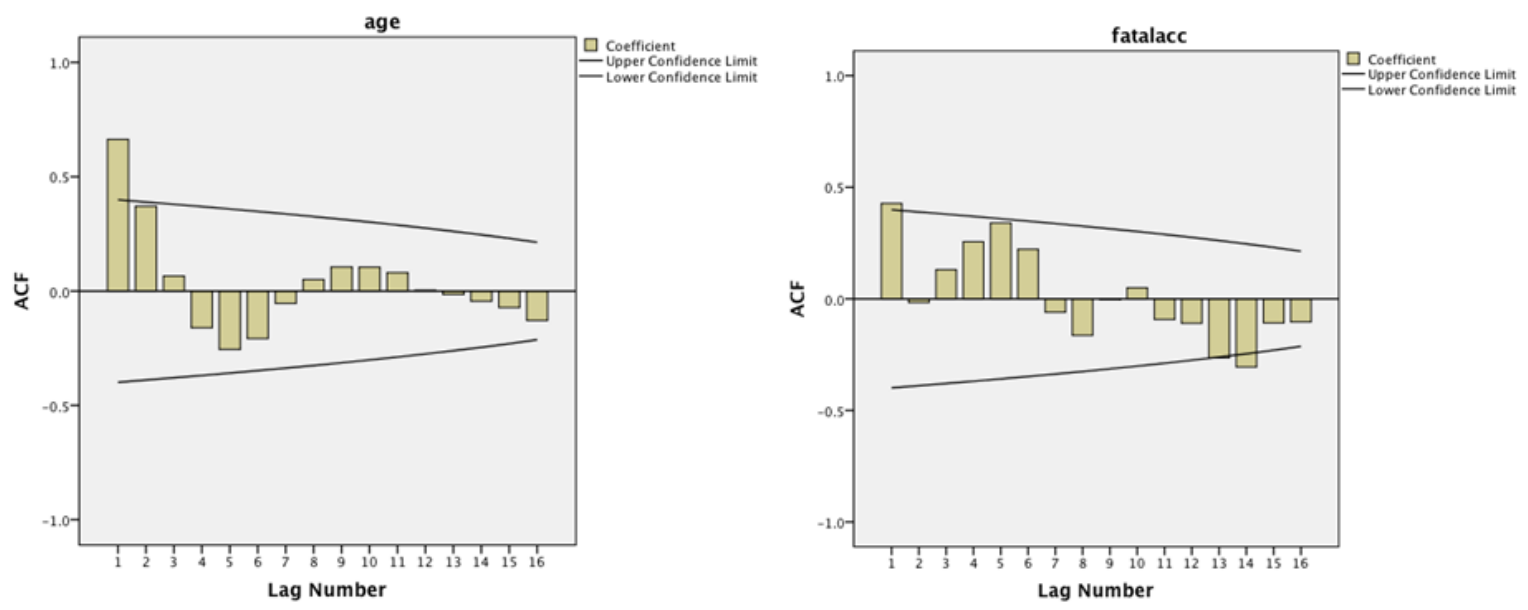

Gambar 2. Auto-Correlation Function (ACF)

Dari hasil pengujian di atas terlihat bahwa data sudah stasioner dan dapat kemudian diolah untuk pengujian Granger. Pengujian Granger dilakukan untuk mengetahui apakah umur pesawat memberikan pengaruh terhadap kecelakaan pesawat. Pengujian ini dilakukan dalam tiga macam lag, yaitu lag 1 tahun, 3 tahun, dan 5 tahun. Berdasarkan hasil Granger Causality Test, didapatkan jumlah kuadrat residual untuk lag 1 tahun, didapatkan $F$ hitung sebesar 5,10. Dengan derajat kebebasan 1 dan 19, maka F kritis adalah sebesar 4,38. Oleh karena F hitung lebih besar daripada $\mathrm{F}$ kritis, maka dapat disimpulkan bahwa umur pesawat memengaruhi tingkat kecelakaan pesawat yang terjadi. Kemudian dilakukan pengujian untuk lag 3 tahun. Pada pengujian ini didapatkan $\mathrm{F}$ hitung sebesar 1,22 dan F kritis pada derajat kebebasan 3 dan 12 sebesar 3,45. Oleh karena itu hipotesis nol diterima yang berarti tidak ada pengaruh umur pesawat terhadap tingkat kecelakaan pesawat. Pada lag 5 tahun, F hitung yang didapatkan adalah sebesar 0,354 dan F kritis pada derajat kebebasan 5 dan 6 adalah sebesar 4,39. Hal ini juga mengindikasikan bahwa umur pesawat tidak memengaruhi tingkat kecelakaan pesawat.

Dari hasil perhitungan tersebut, terlihat bahwa semakin besar lag yang digunakan maka perbandingan antara F hitung dan F kritis semakin tidak signifikan. Dapat disimpulkan bahwa terdapat pengaruh umur pesawat terhadap tingkat kecelakaan pesawat. Namun, semakin besar jangka waktunya, maka pengaruh tersebut akan semakin tidak signifikan.

Selain Analisis time series-causality granger, pengolahan data dilakukan dengan simple regression untuk menguji hipotesis bahwa average age of fleet memengaruhi kecelakaan pesawat. Hipotesis tersebut adalah:

$\mathrm{H}_{0}$ : Tidak terdapat hubungan yang signifikan antara umur pesawat dengan tingkat kecelakaan pesawat

$\mathrm{H}_{1}$ : Terdapat hubungan yang signifikan antara umur pesawat dengan tingkat kecelakaan pesawat

Model yang digunakan dalam pengujian ini adalah sebagai berikut:

$$
y=\alpha+\beta x+e
$$

dengan y merupakan variabel jumlah kecelakaan pesawat dan variabel $\mathrm{x}$ merupakan variabel umur pesawat. Dalam pengujian ini, variabel kecelakaan pesawat merupakan variabel dependen dan variabel umur pesawat merupakan variabel independen.

Data sekunder awal untuk pengolahan data di tahap ini didapatkan dari IATA: World Air Transport Statistics 2012 dan beberapa situs internet. Tabel 1, tabel 2, dan tabel 3 merupakan beberapa hasil dari pengolahan data dengan analisis regresi sederhana. 
Tabel 1. Hasil Uji Korelasi Umur Pesawat dengan Tingkat Kecelakaan

Correlations
\begin{tabular}{|ll|r|r|}
\hline & & fatalacc & \multicolumn{1}{c|}{ age } \\
\hline Pearson & fatalacc & 1.000 & -.502 \\
Correlation & age & -.502 & 1.000 \\
\hline Sig. (1-tailed) & fatalacc &. & .009 \\
& age & .009 &. \\
\hline $\mathrm{N}$ & fatalacc & 22 & 22 \\
& age & 22 & 22 \\
\hline
\end{tabular}

Tabel 2. Ringkasan Model Regresi Sederhana

\begin{tabular}{|l|c|c|c|c|c|}
\hline Model & $\mathrm{R}$ & R Square & $\begin{array}{c}\text { Adjusted R } \\
\text { Square }\end{array}$ & $\begin{array}{c}\text { Std. Error of } \\
\text { the Estimate }\end{array}$ & $\begin{array}{c}\text { Durbin- } \\
\text { Watson }\end{array}$ \\
\hline 1 & $.502^{\mathrm{a}}$ & .252 & .215 & 3.538 & 1.469 \\
\hline
\end{tabular}
a. Predictors: (Constant), age
b. Dependent Variable: fatalacc

Tabel 3. Uji Signifikansi Model Regresi Sederhana

\begin{tabular}{|c|c|c|c|c|c|c|}
\hline \multicolumn{7}{|c|}{ ANOVA $^{a}$} \\
\hline & & $\begin{array}{l}\text { Sum of } \\
\text { Squares }\end{array}$ & df & Mean Square & $\mathrm{F}$ & Sig. \\
\hline \multirow[t]{3}{*}{$\overline{1}$} & Regression & 84.480 & 1 & 84.480 & 6.750 & $.017^{\mathrm{b}}$ \\
\hline & Residual & 250.293 & 20 & 12.515 & & \\
\hline & Total & 334.773 & 21 & & & \\
\hline
\end{tabular}

Hasil pengujian regresi menunjukkan angka korelasi antara variabel umur pesawat dengan variabel tingkat kecelakaan pesawat adalah sebesar 0,009. Angka ini lebih kecil daripada 0,05 sehingga mengindikasikan bahwa terdapat korelasi yang signifikan antara umur pesawat dengan tingkat kecelakaan. Pengujian Durbin-Watson menunjukkan angka 1,469, di mana hal ini mengindikasikan bahwa tidak terjadi auto-korelasi pada model regresi ini. Signifikansi model sebesar 0,017 lebih kecil dari 0,05 menunjukkan bahwa dengan ini $\mathrm{H}_{0}$ ditolak. Oleh karena itu, dapat disimpulkan terdapat hubungan yang signifikan antara umur pesawat dengan tingkat kecelakaan.

Pada awalnya, peneliti mengasumsikan terdapat cross-case interactions dalam model, yaitu:

1. Jumlah kecelakaan dalam 10 tahun (level 1) terhadap region (level 2)

Adanya kemungkinan jumlah kecelakaan dalam 10 tahun banyak terjadi di suatu region dikarenakan satu dan lain hal.

2. Jumlah kecelakaan dalam 10 tahun (level 1) terhadap Age of fleet (level 2)

Adanya kemungkinan jumlah kecelakaan dalam 10 tahun bergantung umur maskapai di suatu negara.

Dari hasil pengolahan data terlihat bahwa interaksi lintas level yang terbukti hanya interaksi kedua, yaitu jumlah kecelakaan dalam 10 tahun terhadap region. Analisis tabulasi silang untuk mengetahui karakteristik setiap kategori maskapai yang digambarkan oleh variabel tingkat keselamatan. Dari hasil analisis tabulasi silang yang dilakukan karakteristik dari kategori maskapai tidak tergambar dengan jelas, berdasarkan jumlah tertinggi dari masing-masing variabel. Persebaran data yang kurang baik disebabkan oleh jumlah maskapai di setiap kategorinya tidak sama banyak. Hal ini menyebabkan modus dari setiap variabel di setiap karakter hampir sama seluruhnya. Namun, karakter tersebut dapat sedikit terlihat dari variabel yang sering muncul di setiap kategori karena persebarannya sedikit lebih jelas terlihat. Dari tingkat keselamatan, maskapai kategori regional memiliki tingkat keselamatan yang sama 
dengan maskapai kategori full-service dan kategori low-cost carrier memiliki nilai yang paling rendah dari ketiga kategori maskapai pada wilayah negara (region).

\section{SIMPULAN}

Dalam model ini terdapat beberapa kategori maskapai yang digunakan dalam penelitian ini, yaitu Tipe 1 (full service carrier), Tipe 2 (low cost), dan Tipe 3 (regional) berdasarkan kategori pelayanan maskapai penerbangan. Pada Uji Tabulasi Silang mengindikasikan bahwa maskapai full-service dan regional cenderung memiliki faktor-faktor service yang lebih baik daripada maskapai low-cost carrier. Analisis Time Series-Causality Granger, mengindikasikan pengaruh umur pesawat terhadap tingkat kecelakaan pesawat. Namun, semakin besar jangka waktunya, maka pengaruh tersebut akan semakin tidak signifikan. Hal ini diperkuat dengan analisis sederhana simple regression yang menyatakan bahwa hubungan yang signifikan antara umur pesawat dengan tingkat kecelakaan.

\section{DAFTAR PUSTAKA}

ATSB Transport Safety Report. (2007). How Old is too old? The Impact of ageing aircraft on aviation safety. Australian Transport Safety Bureau

Boeing. (2016). Statistical Summary of Commercial Jet Airplane Accidents. Washington: Aviation Safety Boeing Commercial Airplanes.

Gujarati, D. N. (2004). Basic Econometrics: Fourth Edition. New York: The Mc.Graw-Hill.

ICAO. (2016). Safety Report. Montreal: International Civil Aviation Organization.

ICAO Indonesia. (2016). http://www.indonesia-icao.org/, (diakses online: 9 Mei 2017)

Hansman, R. J. (2014). Analysis of Impact of Aircraft Age on Safety for Air Transport Jet Airplanes. Cambridge: MIT International Center For Air Transportation.

Kementrian Perhubungan Republik Indonesia. (2013). www.kemenhub.go.id. (diakses online: 27 April 2017)

Mack, R., Jiang, H, Peterson, R. M. (2013). A Disscusion of The Capacity Suply Demand Balance within the Global Commercial Air Transport Industry. Aviation System Analysis Boeing Commercial Airplanes.

Pacheco, R. R., Fernandes, E., Domingos, E M. (2014). Airport airside safety index.. Journal of Transportasion Management, 34, 86-92.

Putri, A. (2011). Evaluasi Kecelakaan Pesawat Terbang Sipil di Indonesia dengan menggunakan Metode Human Factor Analysis dan Classification System (HFACS). Tugas Akhir. Bandung: Institut Teknologi Bandung.

Sadika, E. D. (2013). Mengkaji Kelengkapan Human Factor Analysis dan Classification System dari sisi budara berdasarkan dimensi budaya dari Trompenaars. Tugas Akhir. Bandung: Institut Teknologi Bandung.

Winarto, H. (2012). Sejarah dan Latar Belakang Investigasi (Penyelidikan) Kecelakaan Pesawat. Australia: SMAIAA. 